\title{
Preparation, Investigation and Enzymatic Activity of Mixed Iigand Complexes of Mefenamic Acid and Phenyl Alanine with some Transition Metal
}

\author{
${ }^{1}$ Wessal M. Khamis, ${ }^{1}$ Bayader F. Abbas, ${ }^{1}$ Shaemaa Hadi Abdulsada, \\ ${ }^{1}$ Mustafa Taha Mohammed, ${ }^{2}$ Alaa A. Sultan and ${ }^{2}$ Nedhal M. Khamis \\ ${ }^{1}$ Department of Chemistry, College of Science, Al-Mustansiyah University, Baghdad, Iraq \\ ${ }^{2}$ Department of Chemistry, College of Sceince, University of Diyala, Diyala, Iraq
}

\begin{abstract}
This research contain preparation of transitions metal complexes for metals $\left(\mathrm{Mn}^{+2}, \mathrm{Co}^{+2}, \mathrm{Ni}^{+2}, \mathrm{Cu}^{+2}\right)$ with the mixed ligands of mefenamic acid and L-phenylalanine. The prepared complexes were investigated by using spectra methods of FTIR, UV-visible spectroscopy, molar conductivity, suspicibility magnetic measurements as well as melting points. Stereo chemistry of complexes were accomplished which showed that geometry of mixed ligand Mef:M:Phenyl alanine with $\left(\mathrm{Mn}^{+2}, \mathrm{Ni}^{+2}, \mathrm{Cu}^{+2}\right)$ metal which have the molecular formula $(513,516.7,521.5)$, respectively. Cobalt complex only has the distorted octahedral with molecular formula (588). Enzymatic activity study for prepared $\mathrm{Ni}^{+2}, \mathrm{Cu}^{+2}$ complexes were calculated the possibility of activation and reactivation (for previously inhibited enzymes) deactivation of enzymes $\mathrm{AChE}$. MAO at human serum. These complexes showed ability for activation or reactivation of enzymes activity at human serum. Metal complexes of $\left(\mathrm{Ni}^{+2}, \mathrm{Cu}^{+2}\right)$ were deactivated the enzymatic reaction. The order reaction of enzymatic reaction were achieved and it were first order reaction for $\left(\mathrm{Ni}^{+2}, \mathrm{Cu}^{+2}\right)$ complexes as inhibitors for enzymatic reaction. $\mathrm{K}_{\mathrm{m}}$ and $\mathrm{V}_{\max }$ were calculated for the tow reactions.
\end{abstract}

Key words: Mefenamic acid, phenyl alanine, enzymatic study of metal complexes, MAO, AChE, human serum

\section{INTRODUCTION}

Mefenamic acid chemistry: Mefenamic acid is non-steroidal anti-inflammatory drug. It's mechanism of activity is unknown completely like all (NSAIDS) drug. The mechanism may be attributed to prostaglandine synthesize inhibition (Anonymous, 2008). Mefenamic acid drugs are used for treatment of minor pain and for the many of edema and tissue damage resulting from inflammatory joint disease arthritis (DeRuiter, 2002). At the other side transition metal ions have the ability of interaction to molecules of additional of different biomolecule such that have organic, inorganic water parts residue at human body. It's commonly that ions metal associate to human bio molecule, construct of $\mathrm{N}, \mathrm{O}, \mathrm{S}$ or different donor atom (Krstic et al., 2015). Many pain killer was synthesized from transition metal complexes with drugs. A new pain killer was produced from ferric form of iron with aspirin (iron interaction to aspirin). The prepared complex was absorbed at $\mathrm{pH}$ lower than if aspirin was used alone. This new pain killer exploit the feature of $\mathrm{Fe}^{+2}$ transport and storage of oxygen and electrons because it was found in its reduced form which was consist hemoglobin at human body (Ashiq et al., 2003). Many transition metal complexes with mefenamic acid were prepared. These complexes have an important place within medical chemistry. This can be explained by the interaction between the negative charged molecule with metal of different oxidation state (Chatterjee, 2012). Spectrophotometry study of $\mathrm{Fe}$ (III) ion-Mefenamic acid complex was achieved and characterized by ${ }^{1} \mathrm{H},{ }^{13} \mathrm{CNMR}$, IR, Uv-visible and elemental analysis (Selvaganapathy and Raman 2016). At biological chemical processes, transition metal ions play an important role in the diagnosis and treatment of different diseases (Bojarowicz et al., 1996). Rh ions were used as coordination centre of potential anticancer (Ang and Dyson, 2006). The mechanism which illustrated this coordination centre was such as "Activity by reduction and transferrin-targeted delivery". Hence, the interest is concentrated in the first class research care about with a few pharmacological activities of first row transition metal complexes such as V(II), $\mathrm{Co}$ (II), $\mathrm{Ni}$ (II), $\mathrm{Cu}$ (II) and $\mathrm{Zn}$ (II) which are available and cheap (Sigel et al., 2007; Silva, 1997).

Metal ions have enzymatic activity. These ions have the ability of modify electron from enzyme to substrate or the opposite. Thus was controlling the enzyme-catalyzed reactions (Glusker et al., 1999). Copper was found at many enzyme or protein as active site. This open new gate way of development of coordination complexes which gave new structural, functional aspect similar to nature of protein or enzymes (Mukheljee, 2003).

Corresponding Author: Wessal M. Khamis, Department of Chemistry College of Science, Al-Mustansiyah University, Baghdad, Iraq 
Table 1: Phy sical properties of prepared complexes

\begin{tabular}{|c|c|c|c|c|}
\hline Comp. & Color $(\%)$ & MP & Yield (\%) & Suggested structure \\
\hline $\begin{array}{l}\text { [Mn(Mef)(Phynel-Ala) } \\
\left.\left(\mathrm{H}_{2} \mathrm{O}\right)_{3}\right] 2 \mathrm{Cl}\end{array}$ & Pagde & $213 d^{\prime}$ & 80 & Octahedral \\
\hline $\begin{array}{l}{[\mathrm{Co}(\mathrm{Mef})(\text { Phynel-Ala) }} \\
\left.\left(\mathrm{H}_{2} \mathrm{O}\right)_{3}\right] 2 \mathrm{Cl}\end{array}$ & $\begin{array}{l}\text { Dark } \\
\text { green }\end{array}$ & 220 & 65 & $\begin{array}{l}\text { Octahedral } \\
\text { distorted }\end{array}$ \\
\hline $\begin{array}{l}{[\mathrm{Ni}(\mathrm{Mef})(\text { Phynel-Ala) }} \\
\left.\left(\mathrm{H}_{2} \mathrm{O}\right)_{3}\right] 2 \mathrm{Cl}\end{array}$ & $\begin{array}{l}\text { Light } \\
\text { green }\end{array}$ & 290 & 90 & Octahedral \\
\hline [Cu(Mef)(Phynel-Ala) & Green & 197 & 90 & Octahedrald \\
\hline
\end{tabular}

*Decomposed

\section{MATERIALS AND METHODS}

Physical measurement and analysis: Melting points of prepared complexes were calculated by using gallen $\mathrm{K}_{\mathrm{m}}$ melting point apparatus. FTIR spectra were recorded at Al-Mustansiryah University by using fourier transform Infrared spectrophotometer-Shimadzu in rang of (400-4000) $\mathrm{cm}^{-1}$.

Electronic spectra were determined by using Uv-1650R Shimadzu spectrophotometer with $\left(10^{-3}\right)$ concentration. The magnetic suscepti-bility measurements were achieved on Gouy balance at $\left(25^{\circ} \mathrm{C}\right)$ using $\mathrm{Hg}\left[\mathrm{Co}(\mathrm{SCN})_{4}\right]$ as calibrant on Sherewood magnetic balance. All chemicals were prepared by Fluka and BHD.

Preparation of metal complexes: Preparation of metal mixed ligand complexes were prepared by getting $10 \mathrm{~mL}$ of ethanolic solutions of equal weights with equal ( $1 \mathrm{mmol}$ ) of the first ligand Mefenamic acid, second ligand L-phenyl alanine and metal chloride. All the three different solution were mixed and refluxed for $2 \mathrm{~h}$. Then the mixture were cooled and filtered. The precipitation was gathered and dried (Abid and Abbas, 2013).

The enzymatic activity study: Enzyme activity was measured in healthy human serum as: MAO activity was measured by using Mewen method (McEwen and Cohen, 1963). AChE activity was detected by using Ellman methods (Ellman et al., 1961). Different concentration of complexes was prepared $(0.1,0.01,0)$ to show $\%$ inhibition. Different concentration of substrate was prepared to show Inhibition type, $\mathrm{K}_{\mathrm{m}}, \mathrm{V}_{\text {max }}$. Physical properties were illustrated in Table 1 .

\section{RESULTS AND DISCUSSION}

FTIR-infra red spectra of mefenamic acid: Figure 1 showed the important peaks of the first ligand mefenamic acid. This spectrum showed band at $\left(1772 \mathrm{~cm}^{-1}\right)$ refers to carbonyl group of the acid. Another peak appeared at $\left(1645 \mathrm{~cm}^{-1}\right)$ refer to $(\mathrm{NH})$ group and band at $\left(3308 \mathrm{~cm}^{-1}\right)$
Table 2: Thermogravimetric analysis data for the ligands and Cobalt (II) complexes

\begin{tabular}{|c|c|c|c|c|}
\hline Comp. & $\begin{array}{l}\text { No. of } \\
\text { steps }\end{array}$ & $\begin{array}{l}\text { Losing } \\
\text { atoms }\end{array}$ & $\begin{array}{l}\text { TG weight } \\
\text { loss } \% \\
\text { calc.(Mwt.) }\end{array}$ & $\begin{array}{l}\text { TG weight } \\
\text { loss } \% \\
\text { found }\end{array}$ \\
\hline \multirow[t]{3}{*}{$\begin{array}{l}\mathrm{Co}(\mathrm{Mef}) \text { (Ph-alanine) } \\
\left.\left(\mathrm{H}_{2} \mathrm{O}\right)_{3}\right] 2 \mathrm{Cl}\end{array}$} & 1 & $\begin{array}{l}2 \mathrm{Cl}, 20 \mathrm{H} \\
1 \mathrm{~N}, 15 \mathrm{C}, 1 \mathrm{O}\end{array}$ & $46(271)$ & 46.43 \\
\hline & 2 & $5 \mathrm{H}, 6 \mathrm{C}$ & $22.94(72.85)$ & 24.25 \\
\hline & 3 & $3 \mathrm{H}, 1 \mathrm{C}, 1 \mathrm{~N}$ & $11.02(26.5)$ & 12.90 \\
\hline
\end{tabular}

refer to overlap between the two groups $\mathrm{NH}$ and $\mathrm{OH}$ of mefenamic acid. The bands at $(3111,3061,2914) \mathrm{cm}^{-1}$ refer to $\mathrm{CH}_{3}$ group (Derebe et al., 2002).

FT-infra red spectra of prepared mixed ligand complexes: The stretching band derivatization of $\mathrm{NH}$ residue for amino acid were not indicated for this groups which should be assigned at $3200-3000 \mathrm{~cm}^{-1}$. The probability of absent of $\mathrm{NH}$ beak caused by nitrogen converted in to tertiary nitrogen. Tertiary nitrogen does not show any peak in the region.

The prepared mixed ligand complexes were investigated by using FT-IR measurements. These spectra were illustrated at Table 2 . It had been clear to researcher that $\mathrm{Mn}(I I)$ complex was attached to $\mathrm{OC}^{-} \mathrm{O}^{-}$carboxylic acid of mefenamic acid ligand. This explained the shifting of C-O carboxylic peak to lower vibration from 1157$1155-1024 \mathrm{~cm}^{-1}$. The band of carbonyl of carboxylic acid group was disappeared which gave an evidence for $\mathrm{OCO}^{-}$-metal ion conjugated as showed at Fig. 2 (Shahanaz and Punitha, 2015; Zapala et al., 2016; AlDulimia et al., 2016).

At the other side, the metal ion (MnII) was conjugated to oxygen of carboxylic acid group of amino acid (L-phenylalanine) which can explained the shifting of amino acid carbonyl group to lower vibration by $30 \mathrm{~cm}^{-1}$ from $1645-1610 \mathrm{~cm}^{-1}$. Alanine associated to $\mathrm{Mn}$ (II) from amine group which showed by the shifting of this group to lower frequency by $30 \mathrm{~cm}^{-1}$. The molar ratio was 1 Mefenamic acid: 1 Metal ion: 1 Amino acid.

Spectra of CoII metal ion showed that molar ratio of prepared complex 1 Mefenamic:1 M:1 Phenyl-alanine. The conjugation between the metal ion (CoII) and mefenamic acid was from the oxygen of carboxylic group for mefenamic acid by losing the frequency at (1772) $\mathrm{cm}^{-1}$ which mean that it can explained by resonance state between the two oxygen of carboxylic acid (Silverstein et al., 2005). The frequency of ionic carboxylic group of phenyl alanine was clarified by showing the shifting of spectrum of carbonyl group from the vibration $1683 \mathrm{~cm}^{-1}$ to lower frequency $\left(1635 \mathrm{~cm}^{-1}\right)$ and the weak vibration of $\mathrm{C}-\mathrm{O}$ at $1446 \mathrm{~cm}^{-1}$ was shifted to $1456 \mathrm{~cm}^{-1}$. These proof that the linkage between the metal and amino acid is from the ionic carboxylic group. The amine group of the L-phenylalanine was attached to the metal ion and 


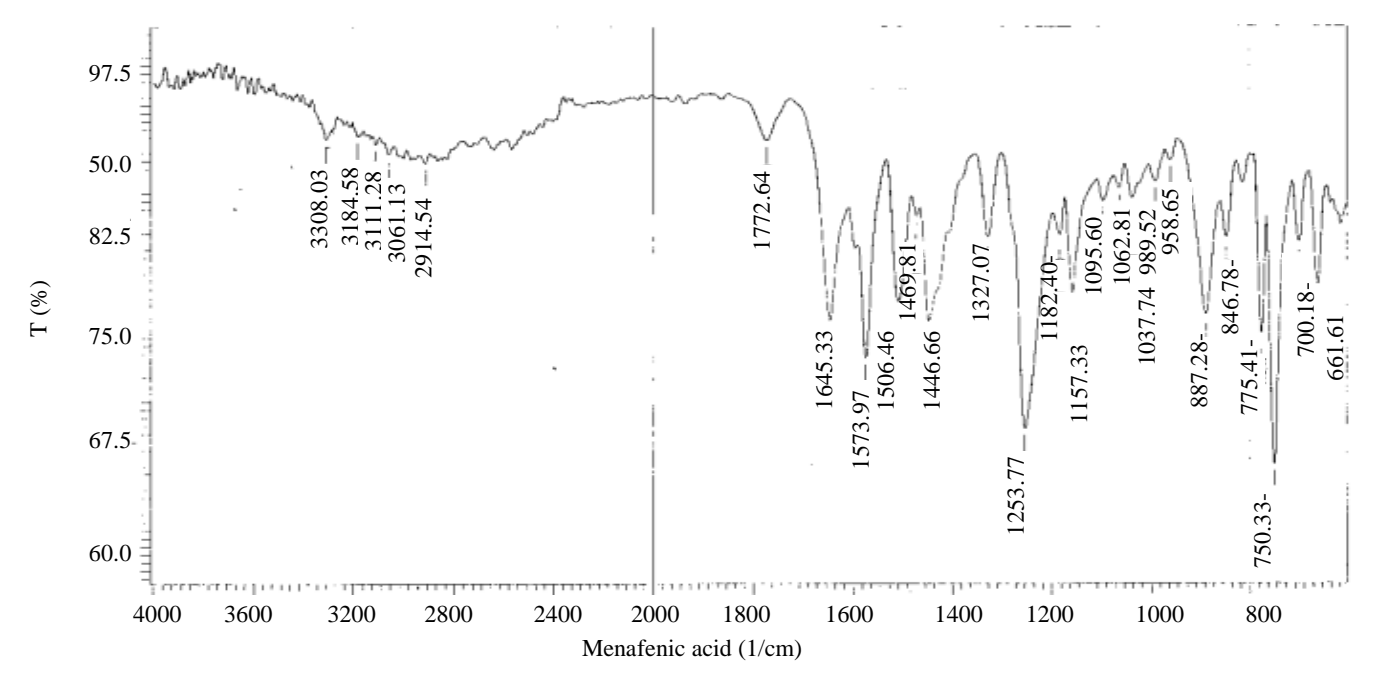

Fig. 1: FTIR spectrum of Mefenamic acid

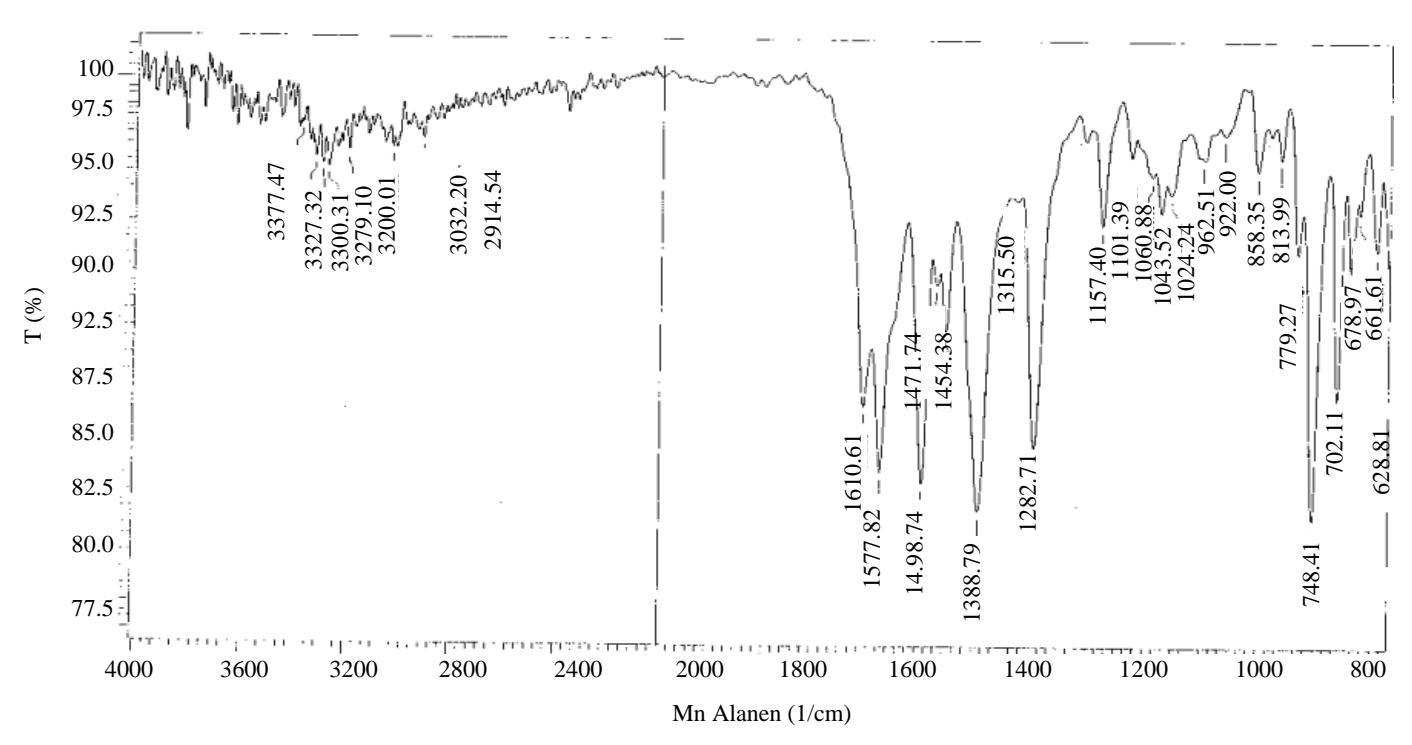

Fig. 2: FTIR spectrum of mixed ligand complex of manganese

this clarify by the shifting of this group by $30 \mathrm{~cm}^{-1}$ for all prepared complexes, Fig. 3 illustrate this explanation. (Rabindra and Mohan, 2000; Derebe et al., 2000; Joseyphus et al., 2006; Patil et al., 2012; Kabbani et al., 2005).

IR spectra of $\mathrm{Ni}$ complex showed shifting for $\mathrm{COO}$ - of L-phenylalanine to lower frequency $(1635-1608) \mathrm{cm}^{-1}$ which prove the linkage between the ionic carboxylic group with the nickle ion. The band at $(1150) \mathrm{cm}^{-1}$ of C-O of carboxylic acid of mefenamic acid was shifted to lower $1095 \mathrm{~cm}^{-1}$ which confirm the coordination of $\mathrm{OC}-\mathrm{O}$ of mefenamic acid with metal iron. Copper complexes gave the same bands and illustrations for linkage with the tow ligands $m$ the drug and amino acid as showed at Fig. 4. The same illustration of $\mathrm{Ni}$ is similarity to $\mathrm{CuII}$ complex.
All complexes assigned $\mathrm{M}-\mathrm{N}$ and $\mathrm{M}-\mathrm{O}$ peaks vibrations at $750-200 \mathrm{~cm}^{-1}$. The $\mathrm{M}-\mathrm{Cl}$ stretching band is supporting bands include a $\mathrm{MO}-\mathrm{C}$ stretching vibration that appears between $(1245-1200) \mathrm{cm}^{-1}$. The $\left(\mathrm{M}-\mathrm{OH}_{2} \mathrm{O}\right)$ bands also were indicated at the positions $(400-450) \mathrm{cm}^{-1}$ and conductivity measurement showed that all complexes were conductance. This gives evidence for the octahedral structure of the four prepared complexes (Fig. 5).

Uv-visible spectra of prepared complexes: Uv-visible spectra of prepared were achieved. All complexes showed bands at $\mathrm{Uv}$ region referred to ... ${ }^{*}$ and $\mathrm{n} .{ }^{*}$ for $\mathrm{C}=\mathrm{O}, \mathrm{NH}$ and $\mathrm{NH}_{2}$. 


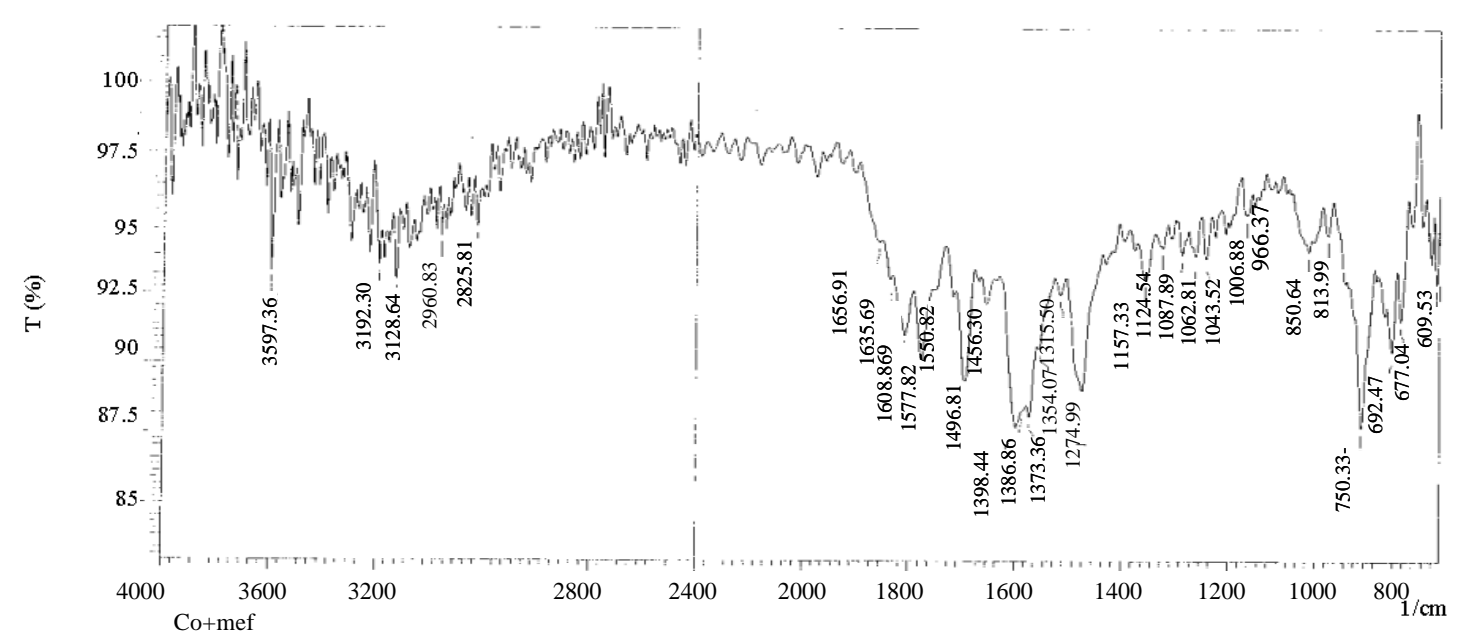

Fig. 3: FTIR spectrum of mixed complex of cobalt

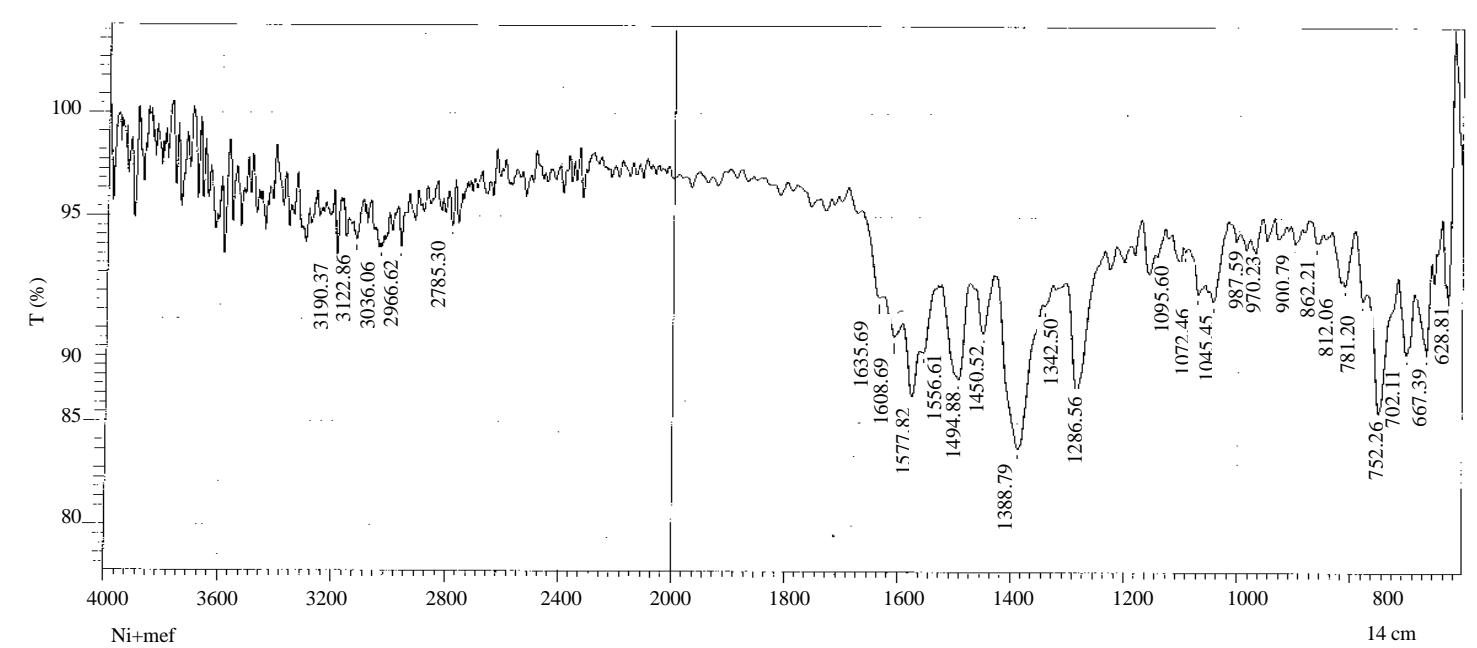

Fig. 4: FTIR spectrum of mixed complex of nickle

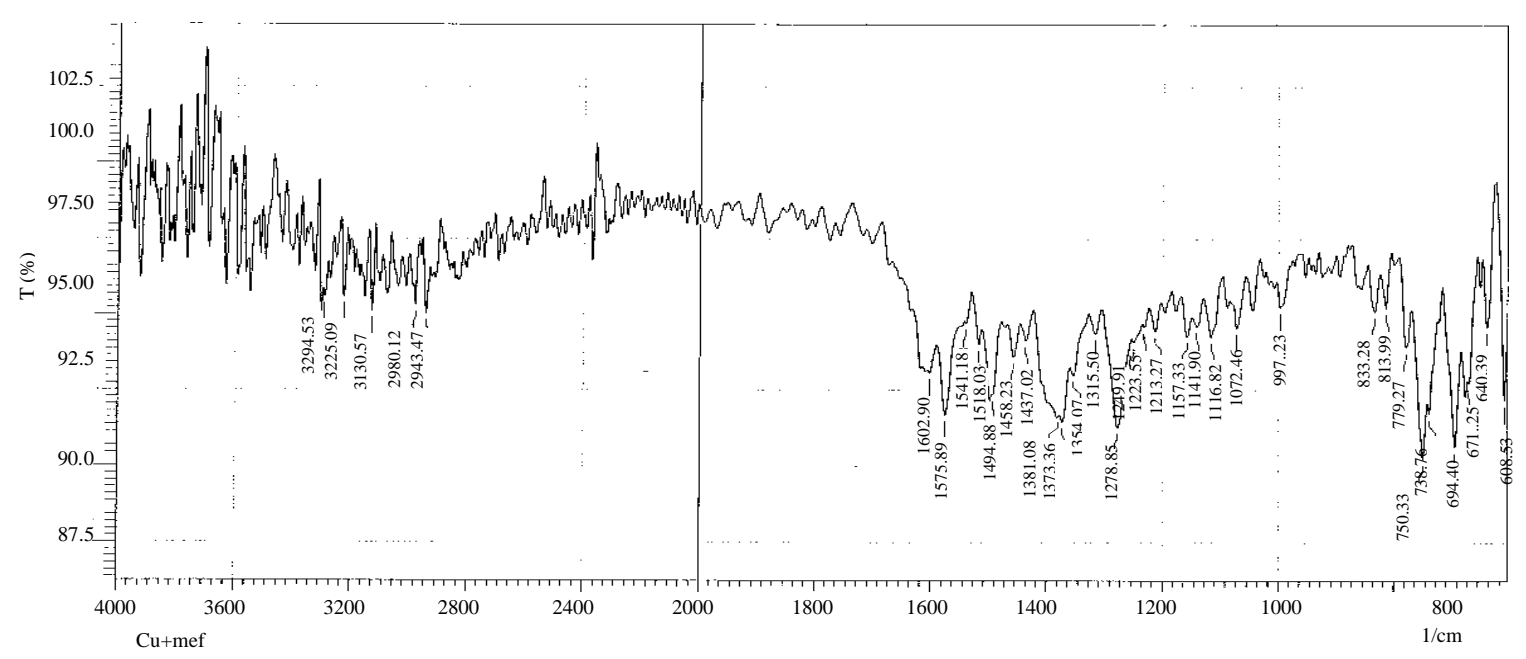

Fig. 5: FTIR spectrum of mixed complex of copper 


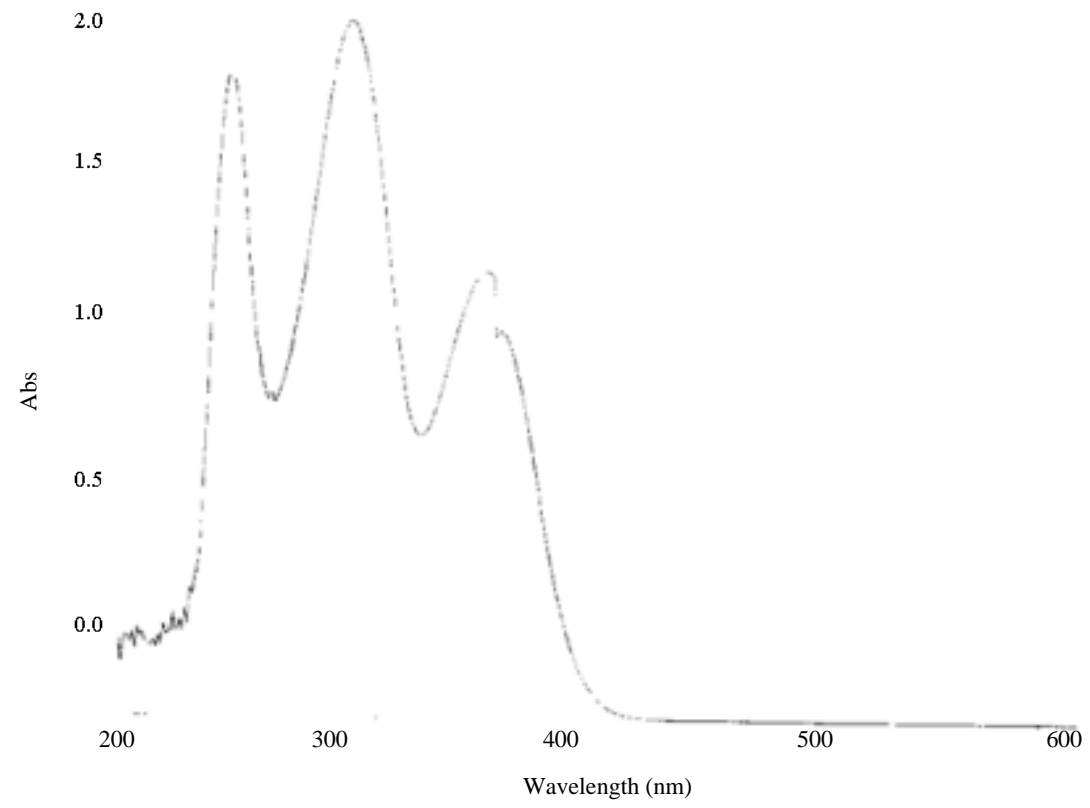

Fig. 6: UV-visible spectrum of mefenic acid

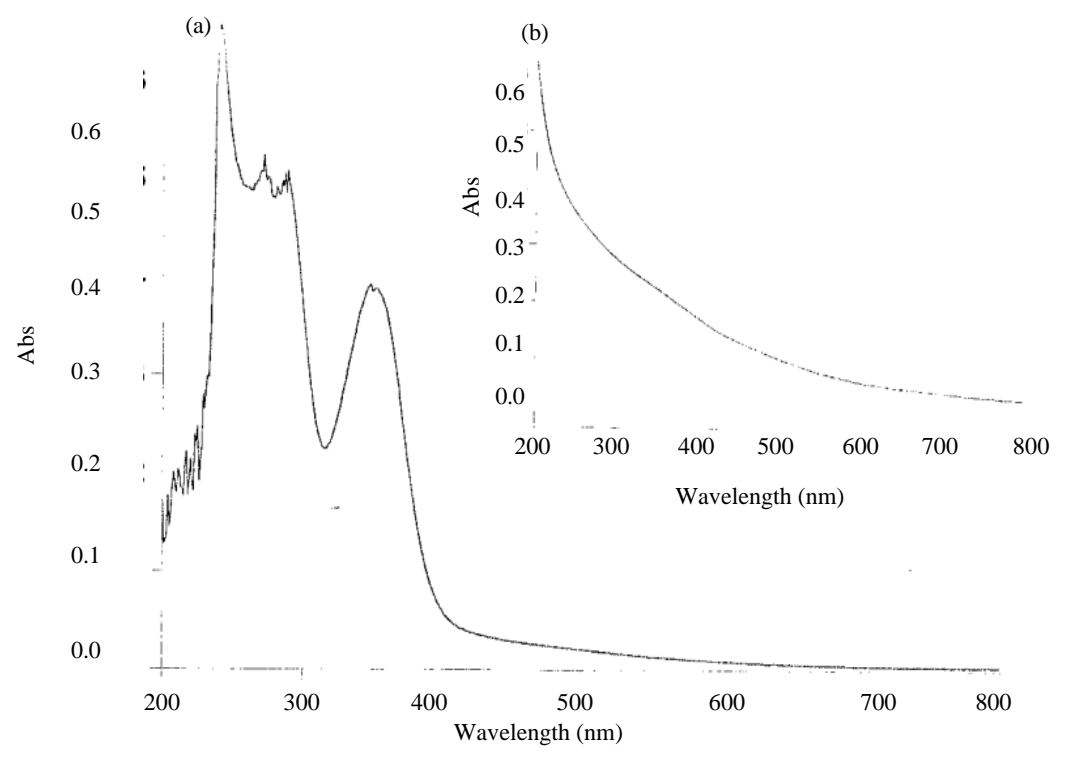

Fig. 7: UV-visible spectrum of mixed ligand complex of manganes

The electronic spectra of Mn complex: The MnII complex showed more than weak one bands around $335-560 \mathrm{~nm}$ bands:

$$
\begin{aligned}
& { }^{6} \mathrm{~A}_{1} \mathrm{~g} \rightarrow{ }^{4} \mathrm{~T}_{1} \mathrm{~g}(4 \mathrm{G})\left(\mathrm{v}_{1}\right),{ }^{6} \mathrm{~A}_{1} \mathrm{~g} \rightarrow{ }^{4} \mathrm{~T}_{2} \mathrm{~g}(4 \mathrm{G})\left(\mathrm{v}_{2}\right) \text { and } \\
& { }^{6} \mathrm{~A}_{1} \mathrm{~g} \rightarrow 4 \mathrm{Eg},{ }^{4} \mathrm{~T} \mathrm{~g}(4 \mathrm{P})\left(\mathrm{v}_{3}\right)
\end{aligned}
$$

This band was overlap together and can be imputed to forbidden $d-d$ transitions. These bands enhanced the chemical structure octahedral geometry. Magnetic moment of the Mn (II) complex is (5.12) BM. Due to single five electrons marking high spin octahedral environment (Negoiu et al., 2005; Fayad et al., 2013; Liwang et al., 2004; Lever, 1984). Figure 6 showed the Uv-vissible spectrum of manganese.

CoII complex showed band at (550) $\mathrm{nm}$ as a broad shoulder assigned to ${ }^{2} \mathrm{~T}_{2} \mathrm{~g},{ }^{2} \mathrm{Eg}$ transition which give us evidence for octahedral distorted geometry. Magnetic moment was (4.3) $\mathrm{BH}$ which deal with the other characterization measurements (Singh and Singh, 2009). Figure 7 showed the UV-vissible spectrum of cobalt. 
(a)

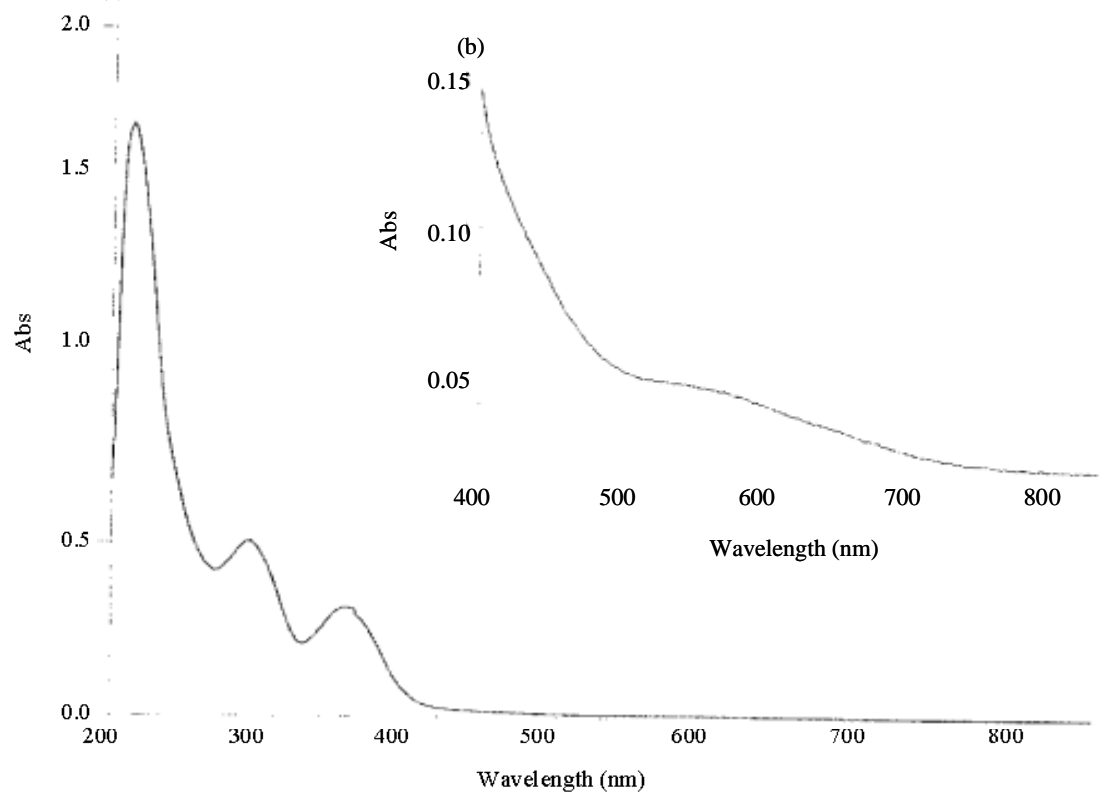

Fig. 8: UV-visible spectrum of mixed ligand complex of cobalt

(a)

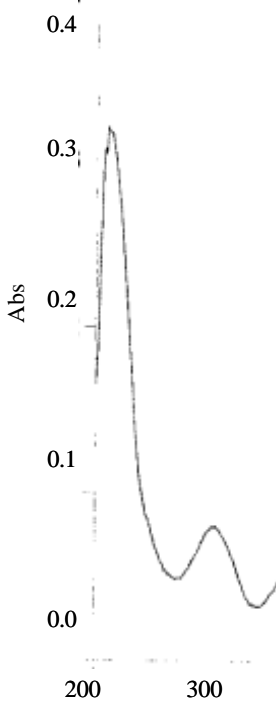

(b)

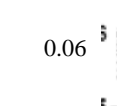
है

$0.05^{5-1}$

0.04 '

0.03 ।

0.02

0.01

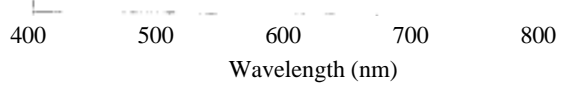

800

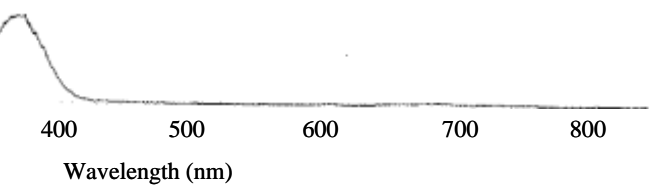

Fig. 9: UV-visible spectrum of mixed ligand complex of nickle

NiIl complex electronic spectrum showed weak band at $650 \mathrm{~nm}$ which can be attributed to d-d forbidden transition from $540-790 \mathrm{~nm}$ which referred to ${ }^{3} \mathrm{~A}_{2} \mathrm{~g}(\mathrm{~F}){ }^{3} \mathrm{~T}_{2} \mathrm{~g}$ $(\mathrm{F})\left({ }_{v_{1}}\right),{ }^{3} \mathrm{~A} \mathrm{~g}(\mathrm{~F}),{ }^{3} \mathrm{Tg}{ }_{(}(\mathrm{F})\left({ }_{v}\right)$ and ${ }^{3} \mathrm{Ag}(\mathrm{F}){ }_{2}^{3} \mathrm{~T} \mathrm{~g}(\mathrm{P}){ }_{1}\left({ }_{v}\right)$ transitions for an octahedral $\mathrm{Ni}$ (II) complex. This data agreed with magnetic susceptibility measurement where (3.22) $\mathrm{BM}$ represented the magnetic moment of nickle mixed ligand complex (Hubner et al., 2011). Figure 8 and 9 showed the UV-vissible spectrum of nickle.
UV-visible spectra of copper complex showed one broad electronic spectrum at $680 \mathrm{~nm}$ returned to the electronic transition ${ }^{2} \mathrm{~B}_{1} \mathrm{~g}^{2} \mathrm{~A}_{1} \mathrm{~g}$. This given data of electronic transition supposed that copper complex made dimer complex with octahedral geometry. Copper magnetic moment was (2.1) BM which fostered the chemical geometry suggestion (Aiyelabola et al., 2017). Figure 10 showed the UV-vissible spectrum of copper. 


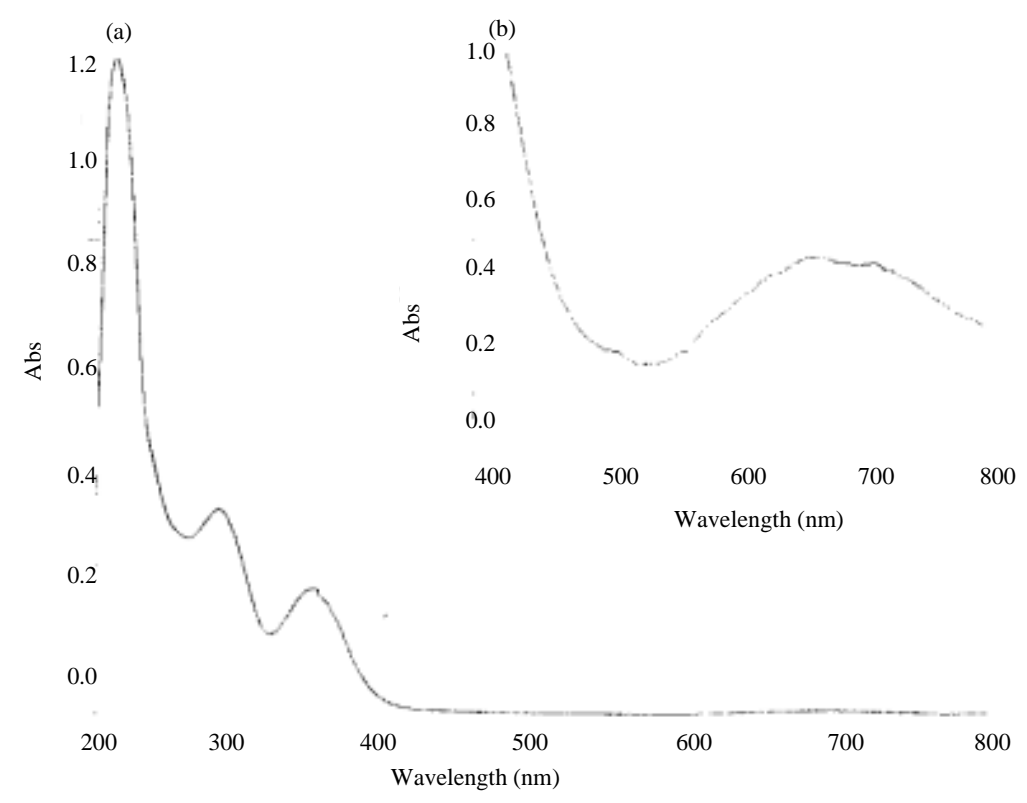

Fig. 10: Uv-visible spectrum of mixed ligand complex of copper

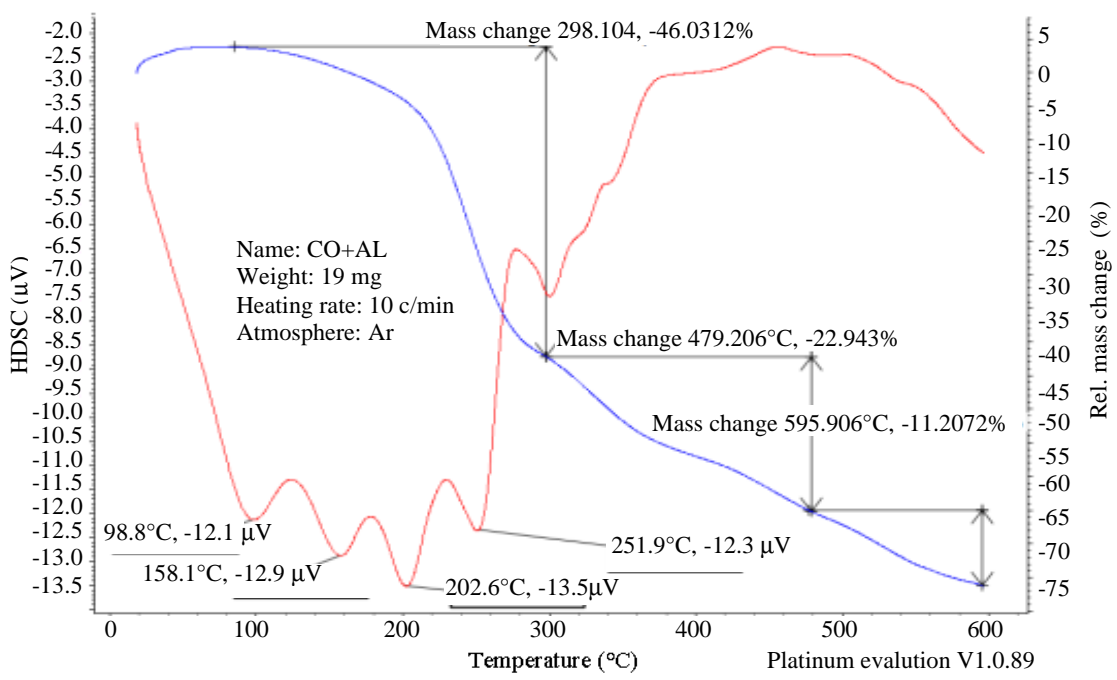

Fig. 11: TGA analysis of mixed ligand complex of cobalt a) Blu line refer to TGA curve (Thermogravimetric analysis), b) Red line refer to DSC curve (Differential Scanning Calorimetry); University of Baghdad/College of education for pure sciences Ibn Al-Haitham Central Service Laboratory

TGA analysis of CoII complex: Thermal analysis was carried out for CoII complex. The heating was appropriately at $50^{\circ} \mathrm{C}$ under nitrogen atmosphere. At $595^{\circ} \mathrm{C}$ temperature, weight losing of complex was calculated. The data which were gained, showed that the thermal decomposition of CoII complex was at three steps under three different temperatures. TGA of cobalt gave idea about thermal stability of its complexes. At the end of thermal decomposition was finished by conformation of cobalt oxide. Table 2 gave a brief statement of TGA/DTG data and Fig. 11 demonstrated thermogram. This data agreed with the suggestion structure of the prepared complex (Kavitha and Lakshmi, 2017; Ahmadi and Amani, 2012).

Enzymatic activity of mixed ligand complexes ( $\mathrm{Ni}, \mathrm{Cu}$ ): The results obtained showed that this complex has inhibitory effect on both MAO and AChE as in Table 3. Type of inhibition and kinetic parameters for MAO and $\mathrm{AChE}$ with complex has been studies and the results 

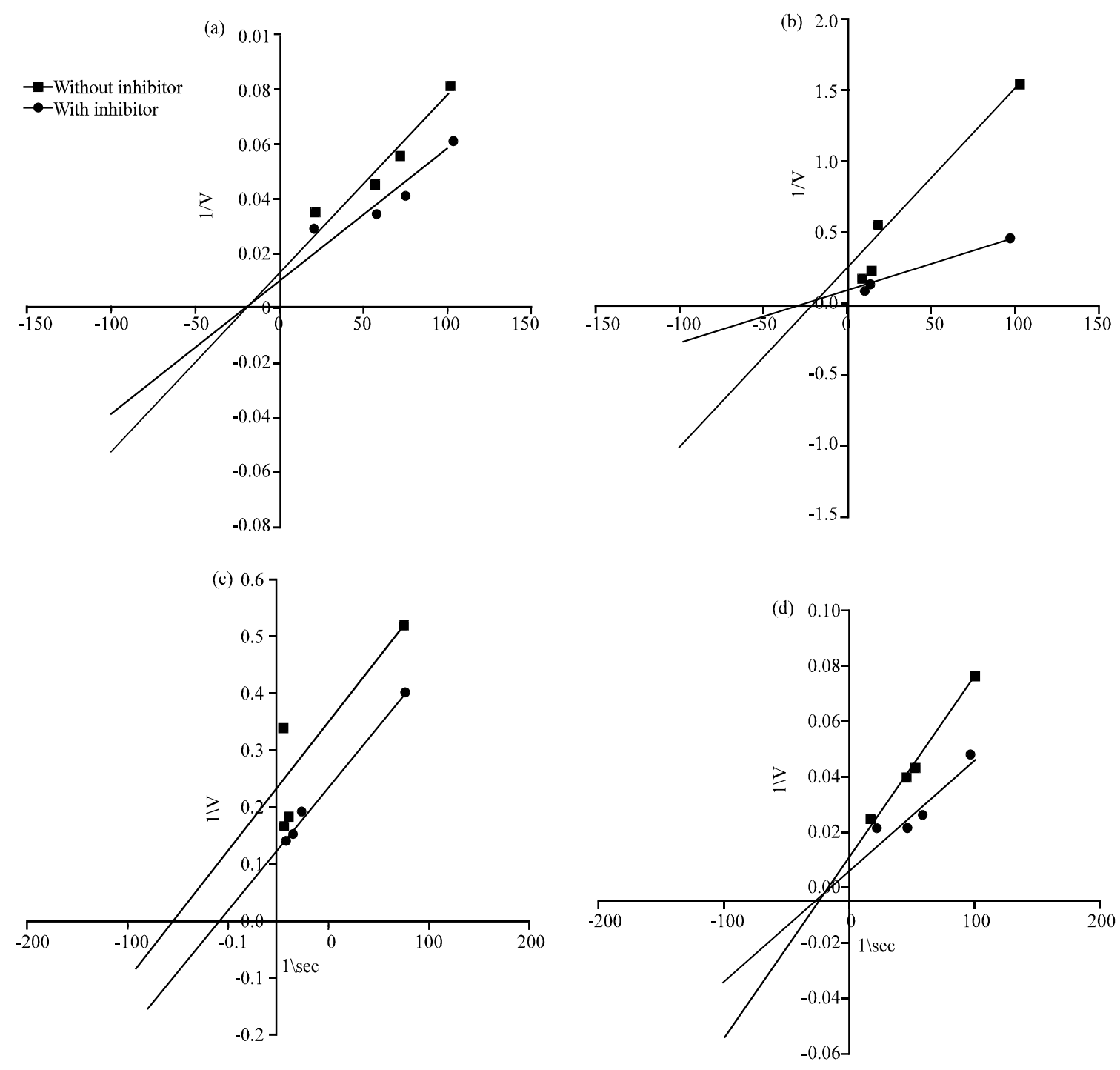

Fig. 12: Llinweaver burk plot for NiII and CuII complex with $\mathrm{MAO}$ and AChE enzyme: a) Ni complex with MAO; b) B Ni complex with $\mathrm{AChE}$; c) $\mathrm{Cu}$ complex with $\mathrm{AChE}$ and d) $\mathrm{Cu}$ complex with $\mathrm{MAO}$

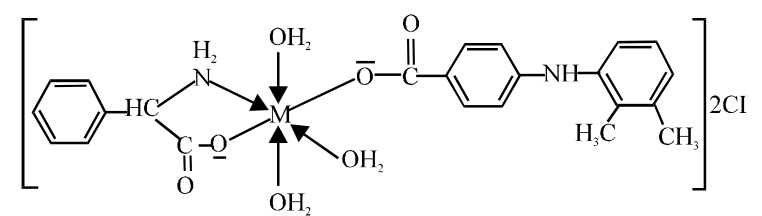

Fig. 13: Prepared complexer ( $\mathrm{M}=\mathrm{MnII}$, CoII, NiII, CuII) showed that competitive inhibition for complex with $\mathrm{MAO}$ and inhibition for complex with $\mathrm{AChE}$ as in Table 4 and Fig. 12.

This complex decrease MAO enzyme activity refer to amine group of complex which attached to active site or to pocket site of enzyme instead of $\left(\mathrm{NH}_{2}\right)$ group of substrate and this complex prohibit (AChE) activity on account of complex attaching to amine acid residue in active site of enzyme and gives rise to inhibition.

The effect of $\mathrm{Cu}$ and Ni complex on Mono Amino Oxidase (MAO) and Acetylcholinesterase (AChE) (Abid and Abbas, 2013; McEwen and Cohen, 1963).

Suggestion structure: All measurements proved that geometry of all prepared complexes with octahedral structure (Fig. 13). 
Table 3: The effect of different concentrations of $\mathrm{Cu}^{+2}$ and $\mathrm{Ni}^{+2}$ complex on $\mathrm{MAO}$ and $\mathrm{AChE}$ activity

\begin{tabular}{lll}
\hline Ni complex & MAO activity & Inhibition (\%) \\
\hline Nil & 38.14 & - \\
0.00001 & 32.01 & 16.07 \\
0.0001 & 21.68 & 43.16 \\
0.001 & 17.23 & 54.82 \\
0.01 & 9.18 & 75.93 \\
Ni complex & AChE activity & Inhibition (\%) \\
Nil & 6.74 & - \\
0.00001 & 6.10 & 9.5 \\
0.0001 & 5.14 & 23.74 \\
0.001 & 3.09 & 54.15 \\
0.01 & 2.16 & 67.90 \\
Cu complex & MAO activity & Inhibition (\%) \\
Nil & 38.14 & - \\
0.00001 & 30.62 & 19.72 \\
0.0001 & 23.47 & 38.46 \\
0.001 & 14.11 & 63.00 \\
0.01 & 7.03 & 81.57 \\
Cu complex & AChE activity & Inhibition (\%) \\
Nil & 6.74 & - \\
0.00001 & 5.91 & 12.3 \\
0.0001 & 4.54 & 32.64 \\
0.001 & 2.80 & 58.46 \\
0.01 & 1.77 & 73.74 \\
\hline
\end{tabular}

Table 4: Kinetic properties of MAO and AChE with $\mathrm{Cu}$ complex and $\mathrm{Ni}$ complex

\begin{tabular}{llll}
\hline Parameters & $\mathrm{V}_{\max }$ & $\mathrm{K}_{m}$ & Inhibition types \\
\hline $\mathrm{A}$ & 66.70 & 0.0500 & Competitive \\
$\mathrm{B}$ & 3.33 & 0.0450 & Competitive \\
$\mathrm{C}$ & 4.34 & 0.0125 & Un competitive \\
$\mathrm{D}$ & 55.50 & 0.0380 & Competitive \\
\hline
\end{tabular}

\section{CONCLUSION}

The IR data clearly showed that at preparing complexes, the mefenamic acid behaves as mono dentate donor ligand involving a carbonyl and the L-phenylalanine as ligand is as bidentate ligand (Kafarska et al., 2017; Smolkova et al., 2016; Zampakou et al., 2014). Study remakes the main data of CuII prepared complex.

\section{ACKNOWLEDGEMENTS}

Acknowledgements to all who contributed to the completion of this research. We thank the head of the Chemistry Department at Mustansiriya University and thanked the educational laboratories in the Department of Chemistry affiliated to the Faculty of Education Ibn Al-Haytham, Baghdad University. We thank and thank all the researchers who contributed to this research.

\section{REFERENCES}

Abid, K.K. and B.F. Abbas, 2013. Synthesis and characterization of some transition metal complexes with a coumarin derivative. Res. Chem. Intermed., 39: 3991-3999.
Ahmadi, R.A. and S. Amani, 2012. Synthesis, spectroscopy, thermal analysis, magnetic properties and biological activity studies of $\mathrm{Cu}$ (II) and $\mathrm{Co}$ (II) complexes with Schiff base dye ligands. Mol., 17: 6434-6448.

Aiyelabola, T., E. Akinkunmi, E. Obuotor, I. Olawuni and D. Isabirye et al., 2017. Synthesis characterization and biological activities of coordination compounds of 4-hydroxy-3-nitro-2h-chromen-2-one and its aminoethanoic acid and pyrrolidine-2-carboxylic acid mixed ligand complexes. Bioinorganic Chem. Appl., 2017: 1-9.

Al-Dulimia, A.A.A., R.A. Al-Hasani andE.A. Yousif, 2016. Synthesis, characterization, theoretical studies and photostabilization of mefenamic acid derivative with some divalent metal ions. Eur. Chem. Bull., 5: 456-464.

Ang, W.H. and P.J. Dyson, 2006. Classical and non-classical ruthenium-based anticancer drugs: Towards targeted chemotherapy. Eur. J. Inorg. Chem., 20: 4003-4018.

Anonymous, 2008. PONSTEL (Mefenamic acid capsules, USP). Sciele Pharma Inc Company, Atlanta, Georgia, USA.https://www.accessdata.fda.gov/drugsatfda docs/label/2008/015034s040lbl.pdf

Ashiq, U., R.A. Jamal and Z.T. Maqsood, 2003. Complexation of commonly used pain killers with iron. J. Chem. Soc. Pakistan, 25: 316-319.

Bojarowicz, H., Z. Kokot and A. Surdykowski, 1996. Complexes of $\mathrm{Fe}$ (III) ions with mefenamic acid. J. pharm. Biomed. Anal., 15: 339-342.

Chatterjee, S., 2012. Encyclopedia of Inorganic Chemistry. Discovery Publishing House Pvt. Ltd., New Delhi, India, ISBN:978-81-8356-874-6,

DeRuiter, J., 2002. Non-Steroidal Antiinflammatory Drugs (NSAIDS). J. Principles Drug Action, 1: 1-26.

Derebe, M.G., V.J.T. Raju and N. Retta, 2002. Synthesis and characterization of some metal complexes of a Schiff base derived from ninhydrin and a, L-alanine. Bull. Chem. Soc. Ethiopia, 16: 53-64.

Ellman, G.L., K.D. Courtney, V. Andres Jr. and R.M. Featherstone, 1961. A new and rapid colorimetric determination of acetylcholinesterase activity. Biochem. Pharmacol., 7: 88-95.

Fayad, N.K., T.H. Al-Noor, A.A. Mahmood and I.K. Malih, 2013. Synthesis, characterization and antibacterial studies of $\mathrm{Mn}$ (II), $\mathrm{Fe}$ (II), Co (II), Ni (II), $\mathrm{Cu}$ (II) and Cd (II) mixed-ligand complexes containing amino acid (L-Valine) and (1, 10-phenanthroline). Chem. Mater. Res., 3: 66-74.

Glusker, J.P., A.K. Katz and C.W. Bock, 1999. Metal ions in biological systems. Rigaku J., 16: 8-17. 
Hubner, M., I. Hauer, C. Muller, D. Rusu and $\mathrm{K}$. Botond et al., 2011. Spectroscopic studies of copper (II) complexes with some amino acid as ligand. Ann. West Univ. Timisoara Phys. Ser., 55: 77-85.

Joseyphus, R.S., C.J. Dhanaraj and M.S. Nair, 2006. Synthesis and characterization of some Schiff base transition metal complexes derived from vanillin and $\mathrm{L}(+)$ alanine. Transition Metal Chem., 31: 699-702.

Kabbani, A.T., H. Ramadan, H.H. Hammud, A.M. Ghannoum and Y. Mouneimne, 2005. Synthesis of some metal complexes of $\mathrm{n}$-[(benzoylamino)thioxomethyl]-aminoacid (HL). J. Univ. Chem. Technol. Metallurgy, 40: 339-344.

Kafarska, K., M. Gacki and W.M. Wolf, 2017. Synthesis, spectroscopic and thermal investigations of metal complexes with mefenamic acid. J. Chem., 2017: 1-7.

Kavitha, N. and P.A. Lakshmi, 2017. Synthesis, characterization and thermogravimetric analysis of $\mathrm{CO}(\mathrm{II}), \mathrm{Ni}(\mathrm{II}), \mathrm{Cu}(\mathrm{II})$ and $\mathrm{Zn}$ (II) complexes supported by ONNO tetradentate Schiff base ligand derived from hydrazino benzoxazine. J. Saudi Chem. Soc., 21: S457-S466.

Krstic, N.S., R.S. Nikolic, M.N. Stankovic, N.G. Nikolic and D.M. Dordevic, 2015. Coordination compounds of $\mathrm{M}$ (II) biometal Ions with acid-type anti-inflammatory drugs as ligands: A review. Trop. J. Pharm. Res., 14: 337-349.

Lever, A.B.P., 1984. Inorganic Electronic Spectroscopy. 2nd Edn., Elsevier, Amsterdam, Netherlands, ISBN:9780444423894, Pages: 863.

Liwang, J.C., M. Zon-Wang, F. Xiao-Long and H. Jim-Wang, 2004. Dinickel complexes bridge by unusual $\left(\mathrm{N}, \mathrm{O}, \mathrm{O}^{\prime}\right)$-coordinated amino acids: Syntheses, structural characterization and magnetic properties. Trans. Met. Chem., 29: 411-418.

McEwen, C.M. and J.D. Cohen, 1963. An amine oxidase in normal human serum. J. Lab. Clin. Med., 62: 766-776.

Mukheljee, R.N., 2003. Bioinorganic chemistry of copper. Indian J. Chem., 42: 2175-2184.

Negoiu, M., T. Rosu, I. Saramet and C.A. Matei, 2005. Complexes of $\mathrm{Cu}$ (II) and $\mathrm{Mn}$ (II) with acylated aminoacids derived from glycine and a-alanine. Ioan V. Nicolescu, 1: 129-133.
Patil, A.R., K.J. Donde, S.S. Raut, V.R. Patil and R.S. Lokhande, 2012. Synthesis, characterization and biological activity of mixed ligand Co (II) complexes of schiff base 2-amino-4-nitrophenoln-salicylidene with some amino acids. J. Chem. Pharm. Res., 4: 1413-1425.

Rabindra, P. and A. Mohan, 2000. Synthesis and characterization of mixed ligand complexes of bio-metals with pyrimidine nucleoside (uridine) and amino acids. J. Chem. Sci., 112: 593-600.

Selvaganapathy, M. and N. Raman, 2016. Pharmacological activity of a few transition metal complexes: A short review. J. Chem. Biol. Ther., 1: 1-17.

Shahanaz, L. and U. Punitha, 2015. Studies on Mefenamic acid complexes of $\mathrm{Mn}(\mathrm{II}), \mathrm{Ni}(\mathrm{II})$ and $\mathrm{Zn}(\mathrm{II})$. Intl. J. Inn. Pharma Biosci. Res. Technol., 2: 196-207.

Sigel, A., H. Sigel and R.K.O. Sigel, 2007. Nickel and its Surprising Impact n Nature. John Wiley \& Sons, Hoboken, New Jersey, USA., ISBN-13:9780-470-01670-8, Pages: 702 .

Silva, J.J.R.F.D., 1997. The Natural Selection of the Chemical Elements: The Environment and Life's Chemistry. Clarendon Press, Oxford, England, UK., ISBN:9780198558422, Pages: 646.

Singh, A.M. and M.P. Singh, 2009. Mixed ligand complexes of copper (II) with pyridine-2-carboxamide and amino acids. J. Indian Counc. Chem., 26: 106-106.

Sliverstien, R., G. Bassler and T. Morrill, 2005. Spectrometric Identification of Organic Compounds. 7 th Edn., John Wiley and Sons, New York, USA.

Smolkova, R., V. Zelenak, L. Smolko and M. Dusek, 2016. Three variants of novel Co(II) complex with NSAID mefenamic acid and N,N'-donor ligand neocuproine. Zeitschrift Kristallographie Crystalline Mater., 231: 715-724.

Zampakou, M., N. Rizeq, V. Tangoulis, A.N. Papadopoulos and F. Perdih et al., 2014. Manganese (II) complexes with the non-steroidal anti-inflammatory drug tolfenamic acid: Structure and biological perspectives. Inorg. Chem., 53: 2040-2052.

Zapala, L., M., Kosinska, E. Woznicka, L. Byczynski and W. Zapala, 2016. Synthesis, spectral and thermal study of La(III), Nd(III), Sm (III), Eu(III), Gd(III) and $\mathrm{Tb}$ (III) complexes with mefenamic acid. J. Therm. Anal. Calorim., 124: 363-374. 